\title{
Preliminary Characterization of Agglutinins from Seven Marine Algal Species
}

\author{
Kanji Hori,* Keisuke Miyazawa, ${ }^{*}$ and Keiji Ito* \\ (Accepted July 15, 1985)
}

\begin{abstract}
We have previously surveyed marine algae for hemagglutinins and detected twenty active species. Here, for elucidating the properties of the algal agglutinins, we examined the agglutinins of seven active species for agglutinating activities toward other biological cells besides erythrocytes, sugar-binding specificities, and effect of heat, $\mathrm{pH}$ and divalent cations on their hemagglutinating activities, using the crude extracts or partially purified agglutinins. As a result, we found that most of the algal agglutinins agglutinated unicellular blue-green algae and mouse tumour cells FM3A, and two to three agglutinins agglutinated yeasts and bacteria. Sugar-binding specificities of the algal agglutinins were different from those of agglutinins from other sources; most hemagglutinating activities were strongly inhibited by many glycoproteins tested and glycopeptidefractions from fetuin, but not generally by monosaccharides, suggesting that algal agglutinins bind specifically to some complex carbohydrates. Algal agglutinins were not affected by addition of divalent cations such as $\mathrm{Ca}^{2+}, \mathrm{Mg}^{2+}$ and $\mathrm{Mn}^{2+}$, unlikely agglutinins from other sources, and were relatively stable at the wide range of temperature and $\mathrm{pH}$. These data indicate that marine algae may provide the available sources for agglutinins with unique properties.
\end{abstract}

Agglutinins, with wide distribution in nature, have been known to be proteins or glycoproteins which specifically recognize and bind some carbohydrates, resulting in producing many unique biological activities. ${ }^{1-3)}$ For the interest compounds as the useful tools in cell biology, immunology, cancer research and other areas of research activities, further efforts for developping the new biological sources in nature and the pharmaceutical properties of agglutinins have been extensively made. Among them, we have focused on algal agglutinins with still poor researches and screened the active components from Japanese marine algae. ${ }^{\theta 2} \quad$ The results and our later screening (unpublished) indicated newly twenty species of marine algae containing hemagglutinating activities. Therefore, we preliminarily examined for some properties of the algal agglutinins using the seven species of active algae and in the discussion of this article compared them to agglutinins from other biological sources. The results indicated that the algal agglutinins have some unique properties, particularly the sugar-binding specificities, different from those of other sources. This paper deals with them.

\section{Materials and Methods}

\section{Algal Specimens}

Algal specimens were collected as follows; a green alga, Ulva pertusa and a red alga, Carpopeltis flabellata at Kata Bay, Wakayama prefecture, in April, 1982 and in May, 1981, respectively. A green alga, Boodlea coacta and a red alga, Hypnea japonica at Ibusuki, Kagoshima prefecture, in March, 1981. A green alga, Enteromorpha linza at Hojo, Ehime prefecture, in May, 1982. A green alga, Codium fragile and a red alga, Gracilaria bursa-pastoris at Fukuyama, Hiroshima prefecture, in June, 1982. After collection, they were freeze-dried as soon as possible and ground on a ball mill to powder. The powdered algae were kept in a desiccator at $-20^{\circ} \mathrm{C}$ until used.

\section{Extraction and Salting-out}

To $10 \mathrm{~g}$ of the powdered alga was added 10 volume of saline and the mixture was stirred at $4^{\circ} \mathrm{C}$ overnight. It was centrifuged at $10,000 \mathrm{rpm}$ for $30 \mathrm{~min}$ and the supernatant was dialized against saline. The inner fraction was made up to $100 \mathrm{~m} l$ with saline and used as the extract for examination. A portion of the inner fraction was saltedout by a saturation to $70 \%$ with ammonium sulfate, and the precipitates were dialized against saline

* Faculty of Applied Biological Science, Hiroshima University, Fukuyama 720, Japan (堸 財治, 富沢啓 戟, 伊藤㤵二：広島大学生物生座学部). 
and used for inhibition test.

\section{Determination of Agglutinating Activity}

A serial twofold dilution of the extract was made in a final volume of $25 \mu \mathrm{l}$ saline in micro V-plate wells using a Takasky microdiluter, To each well an equal volume of one of cell suspension was added. The plate was gently agitated for $30 \mathrm{~s}$ and kept at room temperature for $2 \mathrm{~h}$. Agglutination was observed macro- or microscopically. Agglutinating activity was given as titer, the reciprocal of the highest twofold dilution exhibiting positive agglutination, or as minimum agglutination concentration (MAC, $\mu \mathrm{g}$ protein $/ \mathrm{m} l$ ), the lowest concentration of agglutinin solution to show the agglutination.

\section{Animal and Plant Cells}

The fresh blood from rabbit was washed three times with 50 volume of saline and the packed cells were suspended into saline to be a $2 \%$ cell suspension. To the suspension was added one tenth volume of $0.5 \%$ trypsin in saline and the mixture was incubated at $37^{\circ} \mathrm{C}$ for $1 \mathrm{~h}$. They were washed three times and a $2 \%$ trypsinized rabbit erythrocyte suspension was prepared in saline. The specimens of bacteria, Escherichia coli, Bacillus subtilis, Pseudomonas putida and Flavobacterium sp. were kindly provided by Dr. $H$. Kawakami, Hiroshima University. They were cultured in normal agar medium for $48 \mathrm{~h}$ at $25^{\circ} \mathrm{C}$ to former two species and $35^{\circ} \mathrm{C}$ to others, respectively. The specimens of three species ( $B G A-$ I, II and III abbreviated) of the unicellular bluegreen algae which were not identified, were kindly given by Prof. Y. Ohta, Hiroshima University. They were cultured under the light of $2,000 \mathrm{~lx}$ in inorganic medium ${ }^{7)}$ at $37^{\circ} \mathrm{C}$ for 7 days. The specimens of yeasts, Saccharomyces cerevisiae and Pichia membranaefaciens were similarly given by Prof. Y. Ohta. They were cultured in agar medium containing the extracts of Koji at $30^{\circ} \mathrm{C}$ for $48 \mathrm{~h}$. Mouse tumour cells FM3A were kindly supplied by Dr. S. Ikegami, Hiroshima University. They were cultured under $5 \% \mathrm{CO}_{2}$ in RPMI 1640 medium $^{8)}$ containing $10 \%$ fetal calf serum at $37^{\circ} \mathrm{C}$ for $48 \mathrm{~h}$. The harvested cells of bacteria, blue-green algae and yeasts were washed three times and prepared as the concentrations of $10^{8-7}$ cells $/ \mathrm{m} l$ in saline, respectively. Mouse tumour cells FM3A were prepared as a concentration of $5 \times 10^{7}$ cells $/ \mathrm{ml}$ in $0.02 \mathrm{M}$ phosphate buffer, $\mathrm{pH}$ 6.8 containing $0.85 \% \mathrm{NaCl}$ after washing with the same buffer.

\section{Inhibition Test}

Twofold serially diluted $25 \mu \mathrm{l}$ of sugars or glycoprotein solution were mixed with $25 \mu l$ of agglutinin solution, diluted to the hemagglutination titer 4 against the trypsinized rabbit erythrocytes. The mixture was kept at room temperature for $2 \mathrm{~h}$, then $25 \mu \mathrm{l}$ of the $2 \%$ trypsinized rabbit erythrocyte suspension was added and agglutination was scored after $2 \mathrm{~h}$. The inhibitory activity was given as the minimum inhibition concentration ( $\mathrm{mm}$ or $\mu \mathrm{g} / \mathrm{m} l$ ), the lowest concentration of sugar or glycoprotein at which a complete inhibition of hemagglutination was achieved. The following sugars or glycoproteins were tested. As monosaccharides, D-glucose, Dglucosamine, $\quad N$-acetyl-D-glucosamine, D-glucuronic acid, methyl- $\alpha$-D-glucoside, D-galactose, L-galactose, $N$-acetyl-D-galactosamine, D-galacturonic acid, D-mannose, D-mannosamine, methyl$\alpha$-D-mannoside, D-mannose-6-phosphate, mannitol, inositol, L-rhamnose, L-fucose, D-xylose, D-ribose, 2-deoxy-D-ribose, D-arabinose, L-arabinose and $\mathrm{N}$-acetylneuraminic acid were from Nakarai Chemical Co.. As oligosaccharides, sucrose, maltose, lactose, $\beta$-gentibiose and raffinose were from Nakarai Chemical Co., and $N$-acetylchitobiose from Sigma Chemical Co.. As polysaccharides, gum arabic, laminarin, soluble starch and heparin were from Nakarai Chemical Co. As glycoproteins, fetuin, $\alpha_{1}$-acid glycoprotein, ovalbumin and ovomucoid were from Sigma Chemical Co., and yeast mannan from Nakarai Chemical Co.

\section{Preparation of Glycopeptide-fractions from Fetuin}

Glycopeptide-fractions from fetuin were prepared by the method of Spiro. ${ }^{2}$. One $g$ of fetuin was dissolved in $400 \mathrm{~m} l$ of $0.1 \mathrm{M}$ phosphate buffer, pH 6.5 containing $5 \mathrm{~mm}$ cysteine and $1 \mathrm{~mm}$ EDTA. The solution was incubated with $20 \mathrm{mg}$ of crystalline papain at $37^{\circ} \mathrm{C}$ for $24 \mathrm{~h}$ and similarly with successive $5 \mathrm{mg}$ of the papain. The resultant solution was concentrated and centrifuged, then the supernatant was subjected to gel filtration on a Sephadex G-25 column $(2.5 \times 95 \mathrm{~cm})$ with distilled water. Fractions of glycopeptides eluted as a single peak when monitored by absorbance at $280 \mathrm{~nm}$ and sugar contents were further applied to a Sephadex G-50 column $(2.5 \times 90 \mathrm{~cm})$ with distilled water. The eluate were monitored by absorbance at $280 \mathrm{~nm}$, ninhydrin reaction and sugar contents (Fig. 1). In this gel filtration, glycopeptides were further separated into five fractions (Gp-I, II, III, IV and V). Each frac- 

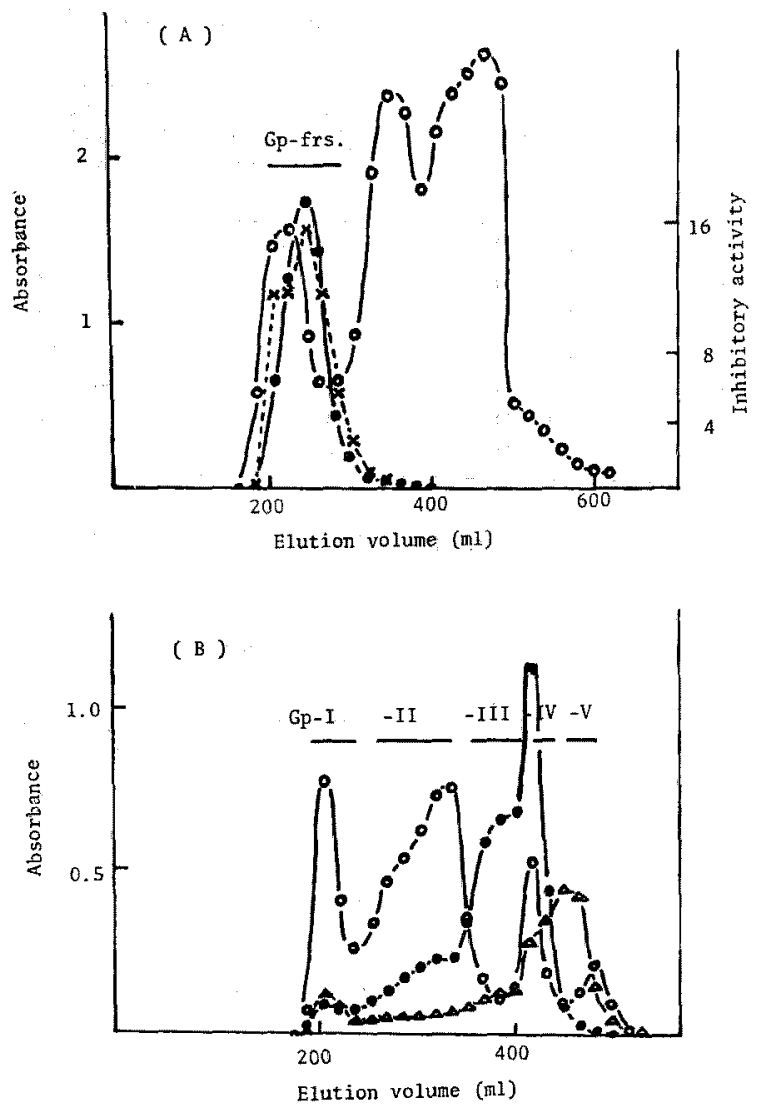

Fig. 1. (A); A Sephadex G-25 gel filtration of the fetuin hydrolyzed with papain. (B); A Sephadex G-50 gel filtration of a glycopeptide-fraction obtained by gel filtration on Sephadex G- 25 . Open circle (O); absorbance at $280 \mathrm{~nm}$, solid circle (e); absorbance at $495 \mathrm{~nm}$ after the treatment by the phenol-sulfate method, triangle $(\Delta)$; absorbance at $570 \mathrm{~nm}$ after ninhydrin reaction, and cross $(x)$; inhibitory activity to the hemagglutinating activity of $C$. flabellata agglutinin (expressed as the reciprocal of the highest dilution exhibiting the inhibitory activity).

tion was dialyzed against distilled water and lyophilized. Respective fraction was examined for the inhibitory activity at a concentration of $2 \mathrm{mg} / \mathrm{m} /$ in saline.

\section{Effect of Heat, pH and Divalent Cations on Hemag- glutinating Activity}

To determine the effect of heat, $\mathrm{pH}$ and divalent cations on hemagglutinating activity, trypsinized rabbit erythrocytes were used. Each one $\mathrm{m} /$ solution of the extract was heated for $30 \mathrm{~min}$ at $30,40,50,60,70,80$ and $90^{\circ} \mathrm{C}$, respectively. The sample solution was cooled in an ice bath, any precipitate formed was centrifuged, and the supernatant was determined for hemagglutinating activity. While, each $2 \mathrm{~m} l$-solution of the extract was dialyzed overnight against $100 \mathrm{~m} /$ of each $0.1 \mathrm{M}$ buffer ranging from pH 3 to 10 . The inner fraction was thoroughly dialyzed against saline to remove the $\mathrm{pH}$ effect, any precipitate formed was centrifuged, and the supernatant was determined for hemagglutinating activity. The buffers used were as follows; acetate buffer for pH 3-5, phosphate buffer for $\mathrm{pH} 6$ and 7, Tris-HCl buffer for $\mathrm{pH} 8$, and carbonate buffer for $\mathrm{pH} 9$ and 10 .

Each $2 \mathrm{~m} l$-solution of the extract was dialyzed against $100 \mathrm{ml}$ of $0.01 \mathrm{M}$ EDTA in $0.01 \mathrm{M}$ phosphate buffer, $\mathrm{pH} 7$ and the hemagglutinating activity of the inner fraction was determined. As the control, a $2 \mathrm{ml}$-solution of the extract was dialyzed against the same buffer without EDTA and similarly determined. Furthermore, to the $0.5 \mathrm{ml}$ of the inner fraction as control, each equal volume of $0.02 \mathrm{M} \mathrm{CaCl}_{2}, \mathrm{MgCl}_{2}$ and $\mathrm{MnCl}_{2}$ was added, 
Table 1. The $\mathrm{pH}$, hemagglutinating activities and contents of protein and sugar of the extracts from seven algal species

\begin{tabular}{lcccrrr}
\hline \multicolumn{1}{c}{ Extract } & $\mathrm{pH}$ & $\begin{array}{c}\text { Hemagglutination } \\
\text { titer } \\
\text { (After dialysis) }\end{array}$ & $\begin{array}{c}\text { Minimum } \\
\text { agglutination } \\
\text { concentration } \\
(\mu \mathrm{g} \text { protein/ml) }\end{array}$ & $\begin{array}{c}\text { Total } \\
\text { hemagglutinating } \\
\text { activity } \\
\text { (Titer } \times \text { volume) }\end{array}$ & $\begin{array}{c}\text { Protein } \\
(\mathrm{mg})\end{array}$ & $\begin{array}{c}\text { Sugar } \\
(\mathrm{mg})\end{array}$ \\
\hline U. pertusa & 6.9 & $8(8)$ & 76.3 & 800 & 61 & 1,800 \\
E. linza & 6.4 & $8(8)$ & 62.5 & 800 & 50 & 1,275 \\
B. coacta & 7.7 & $128(128)$ & 15.0 & 12,800 & 193 & 33 \\
C. fragile & 7.1 & $32(16)$ & 49.4 & 1,600 & 79 & 390 \\
H. japonica & 6.5 & $512(256)$ & 7.2 & 25,600 & 185 & 110 \\
C. fabellata & 6.8 & $64(64)$ & 13.4 & 6,400 & 86 & 160 \\
G. bursa-pastoris & 6.4 & $4(4)$ & 300.0 & 400 & 60 & 300 \\
\hline
\end{tabular}

respectively. They were kept at room temperature for $2 \mathrm{~h}$ and also determined for the hemagglutinating activities.

\section{Determination of Protein and Sugar Contents}

Protein and sugar contents were measured by the methods of Lowry et al. ${ }^{10)}$ and Dubois et al. ${ }^{11}$ ) with bovine serum albumin and D-galactose as standards, respectively.

\section{Results}

Some Properties of the Extracts from Seven Algal Species

Some properties of the extracts from seven algal species are shown in Table 1. The $\mathrm{pH}$ of the extracts were ranging from 6.4 to 7.7 . The contents of protein and sugar of the extracts were different among species, and with the exceptions of $B$. coacta and $H$. japonica all extracts contained the higher amounts of sugars than proteins. In any species, the hemagglutinating activities were detected in the inner fractions after dialysis, indicating that polymers were responsible for the activities.

\section{Agglutinating Activities}

As shown in Table 1, hemagglutinating activity (as MAC) was strong in order of the extracts of $H$. japonica, C. flabellata, B. coacta, C. fragile, $E$. linza, $U$. pertusa and $G$. bursa-pastoris, while the total activity (hemagglutination titer $\times$ sample volume) was high in order of $H$. japonica, $B$. coacta, $C$. flabellata, C. fragile, $U$. pertusa, $E$. linza and G. bursa-pastoris.

The results of agglutinating activities to other animal and plant cells than eryhtrocytes are shown in Table 2. To bacteria, only the extracts of $U$. pertusa, B. coacta and $C$. fragile agglutinated the limited species with any weak activities. On the other hand, all extracts agglutinated almost all species of the blue-green algae tested with relatively strong activities. The strongest activities were detected with the extracts of $C$. flabellata and $G$. bursa-pastoris. Agglutination of the bluegreen algae ( $B G A-\mathrm{I})$ with the extract of $C$. flabellata are shown in Fig. 2. To the yeasts, $S$. cerevisiae and $P$. membranaefaciens, only two extracts of $B$. coacta and $C$. flabellata showed the activities, especially the former agglutinated the cells of $P$. membranaefaciens at a very low concentration of $8 \mu \mathrm{g}$ protein $/ \mathrm{ml}$. Furthermore, most extracts but not those of $U$. pertusa and $E$. linza agglutinated the mouse tumour cells FM3A. It is interesting that the extract of $G$. bursa-pastoris strongly ag. glutinated the tumour cells than erythrocytes. The mouse tumour cells FM3A agglutinated with the extracts of $H$. japonica are shown in Fig. 2.

\section{Sugar-binding Specificities}

The results of inhibition tests are shown in Table 3. There were only four agglutinins that the hemagglutinating activities were inhibited by some monosaccharides; $B$. coacta agglutinin was inhibited by both $25 \mathrm{~mm}$ of L-rhamnose and 100 $\mathrm{mM}$ of D-galacturonic acid, and C. flabellata, $C$. fragile and $E$. linza agglutinins were inhibited by $25 \mathrm{mM}$ of L-rhamnose, $25 \mathrm{mM}$ of $N$-acetyl-Dgalactosamine and $100 \mathrm{~mm}$ of D-mannose-6phosphate, respectively. Others were not inhibited by the concentrations of $100 \mathrm{~mm}$ of any monosaccharides. Oligosaccharides and polysaccharides tested here showed no inhibitory effects to any agglutinins at the concentrations of 100 $\mathrm{mM}$ and $2 \mathrm{mg} / \mathrm{ml}$, respectively.

On the other hand, most agglutinins were inhibited the activities by many glycoproteins tested. In short, fetuin inhibited the activities of all agglutinins with a exception of $E$. linza at the concentrations ranging from 0.03 to $2 \mathrm{mg} / \mathrm{ml}$. $\alpha_{1}$-Acid glycoprotein and ovomucoid also inhibited 
Table 2. Agglutinating activities of the extracts to the bacteria, blue-green algae, yeasts and mouse tumour cells FM3A

\begin{tabular}{|c|c|c|c|c|c|c|c|}
\hline \multirow[b]{2}{*}{ Cell } & \multicolumn{7}{|c|}{ Extract } \\
\hline & $U \cdot$ pertusa & E. linza & B. coacta & C. fragile & $\begin{array}{c}H . \\
\text { japonica }\end{array}$ & $\begin{array}{c}C . \\
\text { flabellata }\end{array}$ & $\begin{array}{c}G . \\
\text { bursa- } \\
\text { pastoris }\end{array}$ \\
\hline \multicolumn{8}{|l|}{ Bacteria } \\
\hline E. coli & 305 & - & 481 & - & - & - & - \\
\hline B. subtilis & - & - & - & 790 & - & - & - \\
\hline P. putida & 305 & - & - & 790 & - & - & - \\
\hline Flavobacterium sp. & - & - & - & 395 & - & - & - \\
\hline \multicolumn{8}{|l|}{ Blue-green algae } \\
\hline$B G A-\mathrm{I}$ & 305 & - & 60 & - & 58 & 27 & 75 \\
\hline$B G A-\Pi$ & 305 & 一 & 60 & 198 & 231 & 27 & 19 \\
\hline$B G A-\mathrm{III}$ & 305 & 500 & 241 & 99 & 116 & 27 & 38 \\
\hline \multicolumn{8}{|l|}{ Yeasts } \\
\hline S. cerevisiae & - & - & 1,850 & - & - & 215 & - \\
\hline P. membranaefaciens & - & - & 8 & - & - & 36 & - \\
\hline \multicolumn{8}{|l|}{ Mouse tumour cells } \\
\hline FM3A & - & - & 481 & 395 & 58 & 215 & 38 \\
\hline
\end{tabular}

The numbers indicate the minimum agglutination concentrations and bars indicate no activity.

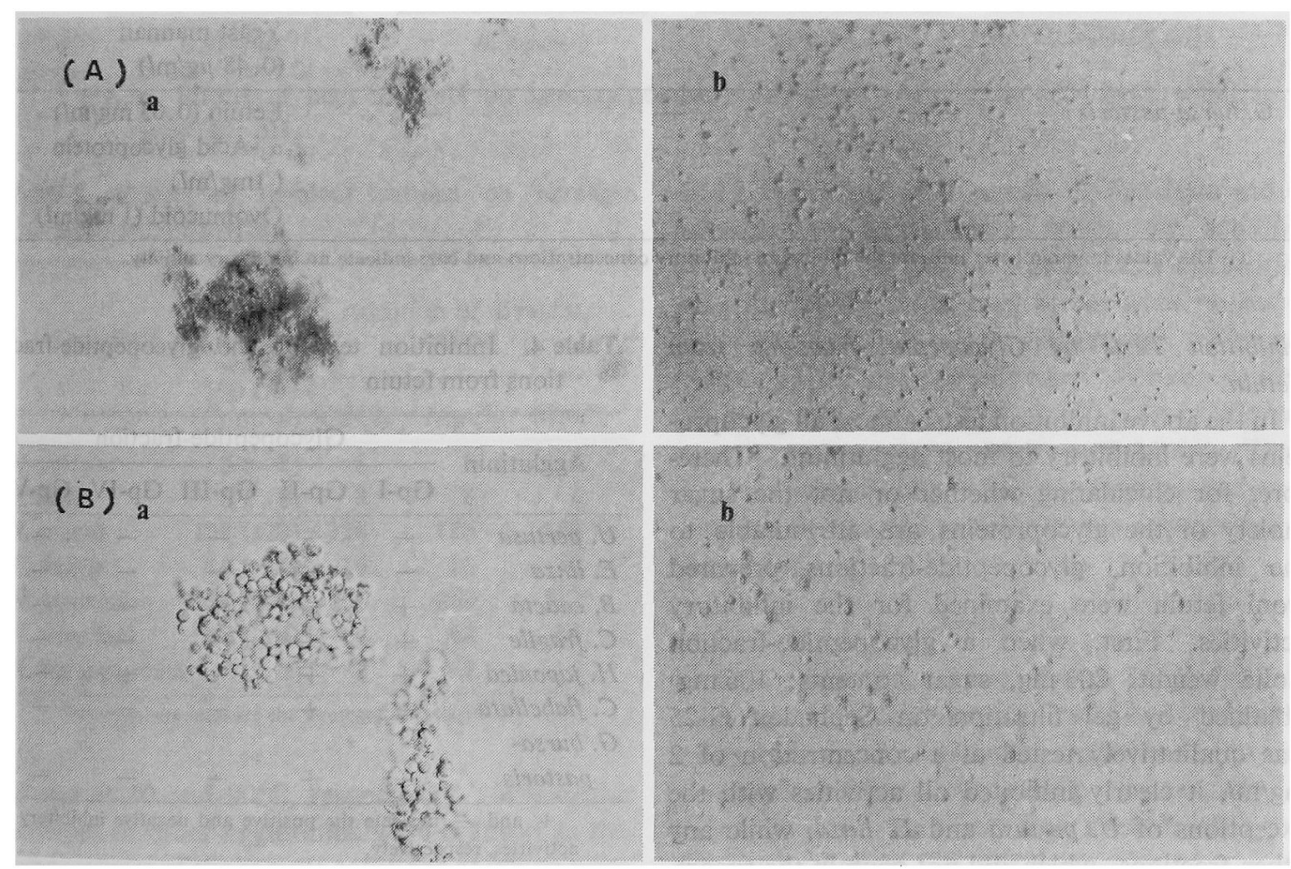

Fig. 2. (A); Blue-green algae agglutinated (a) with the extract of $C$. flabellata and the control (b). $(\times 200)$. (B); Mouse tumour cells FM3A agglutinated (a) with the extract of $H$. japonica and the control $(b) . \quad(\times 200)$.

the activities of most agglutinins. Yeast mannan showed the strongly inhibitory activity only to both agglutinins of $B$. coacta and $C$. flabellata, supporting that only both agglutinins agglutinated the yeasts. Thus, algal agglutinins seemed in general to have affinities to glycoconjugates such as glycoproteins, but not to monosaccharides. 
Table 3. Sugar-binding specificities of algal agglutinins

\begin{tabular}{|c|c|c|c|c|}
\hline \multirow{2}{*}{ Agglutinin } & \multicolumn{4}{|c|}{ Sugar } \\
\hline & Monosaccharide & Oligosaccharide & Polysaccharide & Glycoprotein \\
\hline U. pertusa & - & - & - & Fetuin $(2 \mathrm{mg} / \mathrm{m} /)$ \\
\hline E. linza & $\begin{array}{l}\text { D-Mannose-6- } \\
\text { phosphate }(100 \mathrm{~mm})\end{array}$ & - & - & - \\
\hline B. coacta & $\begin{array}{l}\text { L-Rhamnose } \\
\quad(25 \mathrm{~mm}) \\
\text { D-Galacturonic } \\
\text { acid (100 mm) }\end{array}$ & - & - & $\begin{array}{l}\text { Fetuin }(1 \mathrm{mg} / \mathrm{m} l) \\
\text { Yeast mannan } \\
(0.48 \mu \mathrm{g} / \mathrm{m} l) \\
\text { Ovalbumin }(0.5 \mathrm{mg} / \mathrm{m} l)\end{array}$ \\
\hline C. fragile & $\begin{array}{l}N \text {-Acetyl-D- } \\
\text { galactosamine } \\
(25 \mathrm{~mm})\end{array}$ & - & - & $\begin{array}{l}\text { Fetuin }(0.03 \mathrm{mg} / \mathrm{m} l) \\
\alpha_{1}-\text { Acid glycoprotein } \\
(0.13 \mathrm{mg} / \mathrm{m} /) \\
\text { Ovomucoid }(2 \mathrm{mg} / \mathrm{m} l)\end{array}$ \\
\hline H. japonica & - & - & - & $\begin{array}{l}\text { Fetuin }(0.5 \mathrm{mg} / \mathrm{m} l) \\
\alpha_{1} \text {-Acid glycoprotein } \\
(0.03 \mathrm{mg} / \mathrm{m} l) \\
\text { Ovomucoid }(2 \mathrm{mg} / \mathrm{m} l)\end{array}$ \\
\hline C. flabellata & $\begin{array}{l}\text { L-Rhamnose } \\
(25 \mathrm{~mm})\end{array}$ & - & - & $\begin{array}{l}\text { Fetuin }(0.25 \mathrm{mg} / \mathrm{ml}) \\
\alpha_{1} \text {-Acid glycoprotein } \\
(1 \mathrm{mg} / \mathrm{m} l) \\
\text { Yeast mannan } \\
(0.48 \mu \mathrm{g} / \mathrm{m} l)\end{array}$ \\
\hline G. bursa-pastoris & - & 一 & - & $\begin{array}{l}\text { Fetuin }(0.03 \mathrm{mg} / \mathrm{m} l) \\
\alpha_{1} \text {-Acid glycoprotein } \\
(1 \mathrm{mg} / \mathrm{m} l) \\
\text { Ovomucoid }(1 \mathrm{mg} / \mathrm{m} l)\end{array}$ \\
\hline
\end{tabular}

The values in parentheses indicate the minimum inbibitory concentrations and bars indicate no inhibitory activity.

Inhibition Tests by Glycopeptide-fractions from Fetuin

In the above inhibition tests, almost all glycoproteins were inhibitory to most agglutinins. Therefore, for elucidating whether or not the sugar moiety of the glycoproteins are attributable to the inhibition, glycopeptide-fractions prepared from fetuin were examined for the inhibitory activities. First, when a glycopeptide-fraction (solid weight; $203 \mathrm{mg}$, sugar contents; $106 \mathrm{mg}$ ) obtained by gel filtration on Sephadex G-25 was qualitatively tested at a concentration of 2 $\mathrm{mg} / \mathrm{ml}$, it clearly inhibited all activities with the exceptions of $U$. pertusa and $E$. linza, while any other fractions, which did not contain the sugars, showed no inhibitory activities. Furthermore, when five glycopeptide-fractions separated by successive gel filtration on Sephadex G-50 were tested, with the exceptions of $U$. pertusa and $E$. linza all activities were inhibited by at least one of the glycopeptide-fractions as shown in Table 4. These results clearly indicate that the sugar moiety is attributable to the inhibitory activity,
Table 4. Inhibition test by the glycopeptide-fractions from fetuin

\begin{tabular}{lccccc}
\hline \multirow{2}{*}{ Agglutinin } & \multicolumn{5}{c}{ Glycopeptide-fraction } \\
\cline { 2 - 6 } & Gp-I & Gp-II & Gp-III & Gp-IV & Gp-V \\
\hline U. pertusa & - & - & - & - & - \\
E. linza & - & - & - & - & - \\
B. coacta & + & + & + & - & - \\
C. fragile & + & - & - & - & - \\
H. japonica & + & + & + & + & - \\
C. fabellata & + & + & - & - & - \\
G. bursa- \\
pastoris
\end{tabular}

and in other words algal agglutinins recognize and bind the carbohydrate moiety of fetuin.

Effects of Heat, $p H$ and Divalent Cations on hemagglutinating Activities

The results are shown in Fig. 3 and Table 5. The hemagglutinating activities of $C$. fragile and $H$. japonica were unchanged even when heated for 

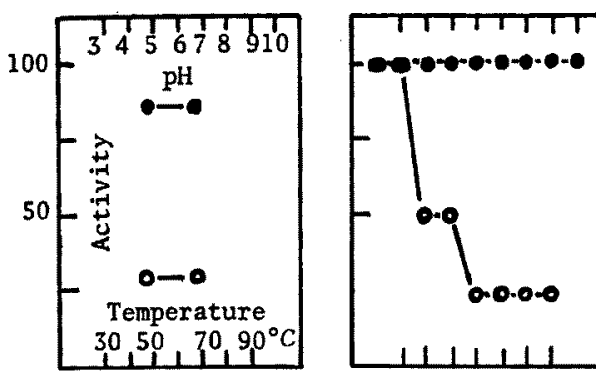

U. periusa

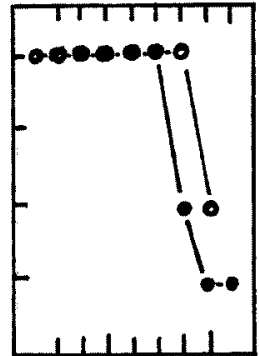

c. fragile

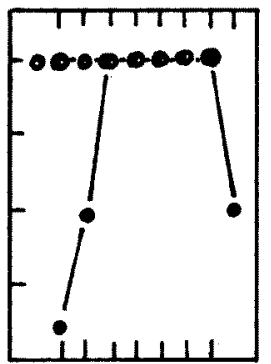

H. japonica

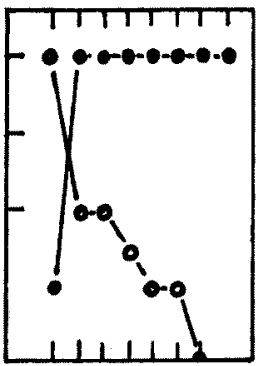

E. linza

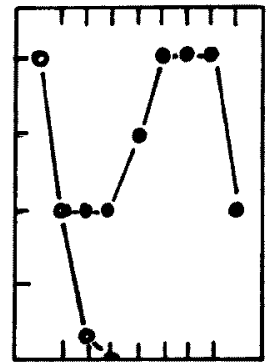

C. fabellata

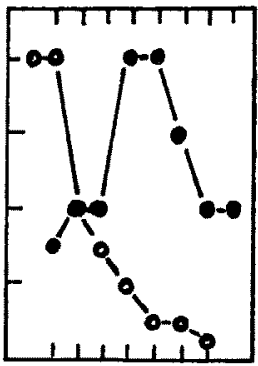

B. coacta

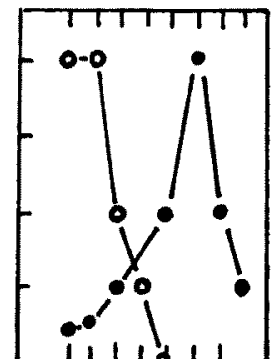

G. bursa-pastoris

Fig. 3. Effects of heat and $\mathrm{pH}$ on hemagglutinating activities. Open circle $(O)$; heat, solid circle (o); pH.

Table 5. Effects of divalent cations on hemagglutinating activities

\begin{tabular}{lrrrr}
\hline & $\begin{array}{c}\text { After } \\
\text { treat- } \\
\text { ment } \\
\text { with }\end{array}$ & \multicolumn{3}{c}{$\begin{array}{c}\text { Addition of divalent } \\
\text { cation }\end{array}$} \\
\cline { 3 - 6 } & $\begin{array}{c}\text { EDTA } \\
\text { (Control) }\end{array}$ & $\mathrm{CaCl}_{2}$ & $\mathrm{MgCl}_{2}$ & $\mathrm{MnCl}_{2}$ \\
\hline U. pertusa & $8(8)$ & 8 & 8 & 8 \\
E. linza & $8(8)$ & 8 & 8 & 8 \\
B. coacta & $128(128)$ & 128 & 128 & 128 \\
C. fragile & $16(16)$ & 16 & 16 & 16 \\
H. japonica & $128(256)$ & 256 & 256 & 512 \\
C. flabellata & $64(64)$ & 64 & 64 & 64 \\
G. bursa-pastoris & $2(2)$ & 2 & 2 & 2 \\
\hline \multicolumn{1}{r}{ The numbers }
\end{tabular}

The numbers indicate the hemagglutination titer.

30 min at 80 and $90^{\circ} \mathrm{C}$, respectively. While, the activities of other agglutinins were reduced as the temperatures of the sample solutions at which were heated became higher. However, excepting $C$. flabellata agglutinin which was most labile to heat, others were observed no complete inactivation even by heating at $60^{\circ} \mathrm{C}$ for $30 \mathrm{~min}$. It was noteworthy that $C$. fragile and $H$. japonica agglutinins were tolerant with heating at very high temperature. All the activities of algal agglutinins were stable in neutral medium, and decreased in acidic and alkaline media in the case of B. coacta, C. flabellata and $G$. bursa-pastoris agglutinins. While, the activities of $U$. pertusa, $C$. fragile and $E$. linza agglutinins were in interest unchanged at the wide ranges of pH 3-10, 3-7 and 4-10, respectively. The activities of all agglutinins were unchanged after the treatments with EDTA or additions of divalent cations such as $\mathrm{Ca}^{2+}, \mathrm{Mg}^{2+}$ and $\mathrm{Mn}^{2+}$. These results indicate that algal agglutinins have no relation to divalent cations in the appearance of the activities.

\section{Discussion}

Algal agglutinins were found to agglutinate some animal and plant cells besides erythrocytes. Among them, the abilities to agglutinate the bacteria seem to be weak in general. Kamiya et al. ${ }^{12}$ ) have also examined a red alga, Cystoclonium purpureum agglutinin for the agglutinating abilities to three kinds of species of marine bacteria and reported that it agglutinated only Microcylus marinus at a relatively high concentration. On the other hand, most of algal agglutinins showed the strong agglutinating activities to any species of the unicellular blue-green algae tested, being speculated to play a role in the interaction between macroalgae and blue-green algae in a marine 
ecological system. However, it is not clear whether or not agglutination of the blue-green algae is characteristic for algal agglutinins because agglutinins from other sources seem not to be examined to the blue-green algae. To mouse tumour cells FM3A, the extracts of many algal species gave the relatively strong agglutinating activities. It has been well known that many agglutinins from the terrestorial plants agglutinated more strongly the transformed cells than the normal cells, ${ }^{3)}$ and this advantage have lead to the activation of studies on agglutinins. The comparison of the agglutinating activities to the transformed and normal cells could not be carried out, but we could demonstrate that algal agglutinins also have the abilities to strongly agglutinate the transformed cells. While, it has been reported that a Triticum vulgaris agglutinin (WGA), a Ricinus communis agglutinin (RCA) and a Phaseolus vulgaris agglutinin (PHA) of the terrestorial plant origin were examined for the hemagglutinating activities to the mouse tumour cells FM3A, and agglutinated them at the concentrations of $500,62.5$ and 125 $\mu \mathrm{g} / \mathrm{m} l$, respectively. ${ }^{13)}$ The extracts of five algal species agglutinated the cells at the concentrations ranging from 38 to $481 \mu \mathrm{g}$ protein $/ \mathrm{ml}$. In comparison, these algal agglutinins were superior to the above terrestorial plant agglutinins, suggesting that the algal agglutinins may be also available as the useful reagents for cancer researches. To the yeasts, only $B$. coacta and $C$. flabellata agglutinins agglutinated, and both hem agglutinating activities were in interest strongly inhibited by the yeast mannan from Saccharomyces cerevisiae.

Up to date, agglutinins from other seven algal species have been subjected to the inhibition tests by sugars using the crude extracts or partially purified specimens by other investigators, and reported that the red algae, Ptilota plimosa, ${ }^{14}$ Palmaria palmata, ${ }^{15}$ Monospora sp. ${ }^{18)}$ and recently Soliera choradalis ${ }^{17)}$ agglutinins were weakly inhibited the activities by $p$-nitrophenyl- $\alpha-\mathrm{D}$ galactoside, $N$-acetylneuraminic acid and $D$ glucuronic acid, D-glucose, and melibiose and sialoglycoprotein, respectively, while other three agglutinins were not by any monosaccharides tested. ${ }^{12,18,18)}$ However, in their inhibition assays, only the limited numbers of monosaccharides were examined and any glycoproteins were not with a exception of the case of $S$. chordalis agglutinin. We tested the inhibitory activities of the large numbers of mono-, oligo- and polysaccharides, and additionally six kinds of glycoproteins. As the results, only limited ones among the monosaccharides very weakly inhibited the activities of four algal agglutinins, and oligo- and polysaccharides tested did not, while almost all glycoproteins strongly inhibited those of most agglutinins. The inhibitory monosaccharides were; L-rhamnose to $B$. coacta and $C$. flabellata agglutinins, D-galacturonic acid to $B$. coacta agglntinin, $N$-acetyl-D-galactosamine to $C$. fragile agglutinin and D-mannose-6-phosphate to $E$. linza agglutinin. They were different from such the inhibitory monosaccharides reported to other algal agglutinins as previously mentioned, and were also unusual ones with a exception of $N$-acetyl-Dgalactosamine when referred to the inhibitory monosaccharides against many agglutinins from other sources, although it has been mentioned to date that an anti-B agglutinin ${ }^{20)}$ of a bacterium, Streptomyces sp. and a few agglutinins ${ }^{2,21)}$ from some fish eggs were L-rhamnose-specific, and mannan-binding glycoprotein $\mathrm{s}^{22,23)}$ from the hepatocytes of some animals were D-mannose-6phosphate-specific. While, D-galacturonic acidspecific agglutinins seem not to be reported. Furthermore, in comparison that many agglutinins from other sources recognize other simple sugars with the same configuration at C-3 and C-4 in the pyranose ring of a inhibitory monosaccharide, ${ }^{24)}$ it is characteristic that the above algal agglutinins which were inhibited by some monosaccharides, did not recognize any other simple sugars with the same configuration at $\mathrm{C}-3$ and $\mathrm{C}-4$ in the pyranose ring of the inhibitory monosaccharide. Finally, although L-rhamnose inhibited the activities of two algal agglutinins, other inhibitory monosaccharides did only one agglutinin but not others. Therefore, it seems at present that the simple sugar as the common inhibitor for algal agglutinins do not exist.

Additionally, we examined the glycopeptidefractions from fetuin for inhibitory activities to the algal agglutinins, for elucidating whether the sugar moieties of glycoproteins which showed the strongly inhibitory effects to most algal agglutinins are attributable to the inhibition. As the results, all agglutinins inhibited by fetuin were also inhibited by the glycopeptide-fractions prepared from fetuin. Whereas, they were not inhibited by any simple sugars which constitute the carbohydrate moiety of the glycoprotein. These clearly indicate that their algal agglutinins specifically recognize the structure of the complex carbohydrate in the glycoprotein. Interestingly, all 
glycoproteins tested have commonly sugar chains with $N$-glycosidic linkage, though a few of them have also $O$-glycosidic ones, saggesting that many algal agglutinins have the binding specificities to the sugar chains of $\mathrm{N}$-glycosidic type.

In the stabilities for heat and $\mathrm{pH}$, it was noteworthy that $H$. japonica and $C$, fragile agglutinins were tolerant at very high temperature, and $U$. pertusa, C. fragile and E. linza agghutinins were stable at a wide range of $\mathrm{pH}$. Generally, algal agglutinins seem to be similar to those from other sources in the stabilities for heat and $\mathrm{pH}$. However, the activities of algal agglutinins were not affected by divalent cations, unlikely many agglutinins ${ }^{2)}$ from other sources.

Thus, we could demonstrate in this study that algal agglutinins have some unique properties, differed from those of agglutinins from other sources. It prompted to us that marine algae may provide the valuable sources for unique agglutinins. Recently, we isolated and characterized the agglutinins with many unique properties from three different species of marine algae. They will be published in near future.

\section{Acknowledgments}

We wish to thank to Prof. K. Hashimoto and Dr. N. Fusetani, the University of Tokyo, for the suggestion and advice for the manuscript. We are indebted to Prof. Y. Ohta, Dr. S. Ikegami and Dr. H. Kawakami, Hiroshima University, for kindly providing with animal and plant cells. This work was supported in part by a Grant-inAid for Scientific Research from the Ministery of Education.

\section{References}

1) N. Sharon and H. Lis: Science, 177, 949-959 (1972).

2) E. R. Gold and P. Balding: Receptor-Specific Proteins, Plant and Animal Lectins, Excerpta Media, Amsterdam, 1975, pp. 1-440.

3) G. L. Nicolson: Biochim. Biohpys. Acta, 458, 1-72 (1976).
4) I. J. Goldstein and C. E. Hayes: $A d v$. Carbohyd. Chem. Biochem., 35, 127-340 (1978).

5) H. Lis and N. Sharon: in "The Biochemistry of Plants", Vol. VI (ed. by P. K. Stumpt and E. E. Conn), Academic Press, New York, 1981, pp. $371-447$.

6) K. Hori, K. Miyazawa, and K. Ito: Bull. Japan. Soc. Sci. Fish., 47, 792-798 (1981).

7) E. G. Pringshein and W. Wissner: Arch. Microbiol., 40, 231 (1961).

8) G. E. Moore, R. E. Gerner, and H. A. Franklin: J. Am. Med. Assoc., 199, 519 (1967).

9) R. G. Spiro: J. Biol. Chem., 237, 382-388 (1962).

10) O. H. Lowry, J. N. Rosebrough, A. L. Farr, and R. J. Randall: J. Biol. Chem., 193, 265-275 (1951).

11) M. Dubois, K. A. Gilles, J. K. Hamilton, P. A. Rebers, and F. Smith: Anal. Chem., 28, 350-356 (1956).

12) H. Kamiya, K. Shiomi, and Y. Shimizu: J. Nat. Prod., 43, 136-139 (1980).

13) M. Hozumi, S. Miyake, F. Mizunoe, T. Sugimura, R. F. Irie, K. Koyama, M. Tomita, and T. Ukita: Int. J. Cancer, 19, 393-401 (1972).

14) D. J. Rogers, G. Blunden, and P. R. Evans: Med. Lab. Sci., 34, 193-200 (1977).

15) H. Kamiya, K. Ogata, and K. Hori: Bot. Mar., XXV, 537-540 (1982).

16) H. Kamiya: Bull. Japan. Soc. Sci. Fish., 48, 1365 (1982).

17) D. J. Rogers, and G. Blunden: Bot. Mar., XXII, 459-462 (1983).

18) K. Shiomi, H. Kamiya, and Y. Shimizu: Biochim. Biophys. Acta, 576, 118-127 (1979).

19) K. Shiomi, H. Yamanaka, and T. Kikuchi: Bull. Japan. Soc. Sci. Fish., 47, 1079-1084 (1981).

20) Y. Fujita, K. Oishi, K. Suzuki, and K. Imahori: Biochemistry, 14, 4465-4470 (1975).

21) D. J. Anstee, P. D. J. Holt, and G. I. Pardol: Vox Sang, 25, 347-359 (1973).

22) H. D. Fisher, A. Gonzalez-Nonega, W. S. Sly, and D. J. Morre: J. Biol. Chem., 255, 9608-9615 (1980).

23) G. G. Sahagian, J. Distler, and G. W. Jourdian: Proc. Natl. Acad. Sci. USA, 78, 4289-4293 (1981).

24) O. Makela: Ann. Med. Exp. Biol. Fenn., 35, supll. 11, 1-133 (1957). 